\title{
Vocalizing the "Local": Exploring the Cultural Milieu Along Coastal Maharashtra
}

\author{
Durga Kale \\ University of Calgary, Calgary, Canada
}

\begin{abstract}
The return to the study of localized aspects of culture and tradition is unravelling the various layers of a regional cultural milieu in academic study. Following the vein of regional exploration, this paper explores the case of Konkan, along the west coast of India, for the vernacular religious traditions. The mythic hero Parshurama mentioned in the text of Sahyadri Khanda features as a prominent hero along the Konkan coast and numerous places and performative traditions have retained the mythical base of this narrative as a part of local history. Ritual significance of naming certain sites and the connection between temples and other archaeological material sources with a narrative thread form the crux of this discussion on local culture in Konkan. The aspect of orality in the narrative scheme is often overlooked in the study of regional culture, and this exploration makes a case for the interdisciplinary approach of textual sources, ethnographic and oral accounts along with the data pertaining to material culture in such a study. The paper offers an entry point into the examination of religious texts and local performative tradition hinged on narratives of space that have shaped the vernacular culture to this day. This exploration will offer a case-study for an interdisciplinary investigation into local cultures that in turn enrich the knowledge on popular socio-religious currents.
\end{abstract}

Keywords: Konkan, Western India, Vernacular religion, Local culture, Parshurama, Sahyadri Khanda, Religious Narratives

The region along the west coast of India is known for its unique cultural milieu. The coastal villages along in the modern state of Maharashtra in western India revere the traditional narratives on the strip of land named as Konkan reclaimed from the Arabian Sea. This paper is aimed at the regional culture in Konkan which is a product of medieval textual tradition and oral narrative culture. Furthermore, the nomenclature for the places, connection of several locales through a narrative link, and deification of the sites will contribute to the discussion on the vernacular culture. The paper is divided in three main sections: The discussion on literary sources, examples from modern belief system as gleaned from the field visits, and a discussion on the intimate connection between these two components in the making of the vernacular culture in Konkan.

\section{The Narrative Backdrop}

The modern Hindu cultural practices in India are largely a product of the medieval traditions. The Puranas (lit. old or ancient), for instance, are the corpus of medieval texts on which modern Hindu ideas and practices are largely based on. Several texts, such as Brahmanda Purana, Shiva Purana, and Skanda Purana are named as

Durga Kale, Ph.D. candidate, Department of Classics and Religion, University of Calgary, Calgary, Canada. 
the main Puranas with several regional recensions. Sahyadri Khanda, a regional text in Sanskrit produced during the medieval period (c. 700-1700 CE) (Habib, 2008) is credited for bourgeoning the narratives on religious geography of Konkan affiliated with Hinduism. Almost all the references on religious milieu in Konkan thereafter, such as Udayasundarikatha (Sharma, 2004) ${ }^{1}$ and reports on religion by British surveyors (Enthoven, 1920-1922) draw from the trove of narratives of Sahyadri Khanda. This medieval text is named after the Sahyadri hills on the eastern side of the Konkan coast. Konkan sits between Arabian Sea to the west and the Sahyadri hills to the east. This geographical situation is drawn upon in the narratives of Sahyadri Khand $a$ and is woven into the religious narratives as will be discussed in the paper.

A designation of Stahala-Mahatmya ${ }^{2}$ is frequently associated with texts, such as Sahyadri Khanda (SK, hereafter), which speak to the site specific religious and cultural significance. SK encapsulates regional religious significance while self-proclaiming to be a part of Skanda Purana (Da Cunha, 1877). This self-proclamation addresses the claim for authority as being a part of Skanda Purana, which is well-known and revered to this day. Rohlman (2011) elaborated a similar example of Saraswati Purana from Gujarat that asserts the parity of its own regional tradition with that of Pan-Indic culture. SK, much like Saraswati Purana, employs geography to define cultural boundaries and to transcend them. The extant folios of SK further employ a characteristic Puranic narrative scheme (Rocher, 1986; Levitt, 1982) ${ }^{3}$ of anchoring various aspects of Hindu cosmic order onto the physical landscape through the agency of legends and animating the landform.

SK delves into an elaborate narration of the creation story of Konkan by the mythic hero Parashurama (Da Cunha, 1877), the arrangement of the seven islands of Konkan (sapta-Konkan) (Deshpande, 2010) ${ }^{4}$, concepts of heaven and hell and lastly, elaborate narratives on dissolution of the world, and possible redemption by Shiva (Da Cunha, 1877; Deshpande, 2010). The mythological account for the creation of the coastal land follows the story of Parashurama, who was banished from earth after killing a sizable number of warriors (Deshpande, 2010). The story goes that this banished hero then stood atop Sahyadri hills and shot an arrow into the sea as a demand for new land according to the descriptions of Sahyadri Khanda. The sea then receded, exposing the coastline between Sahyadri hills and the sea. This episode is reiterated by a local priest to a British officer in 1800s according to the records (Crawford, 1909). The continuity and belief in this lore appears to have followed a relatively stable form of oral and written retrieval extant to this day. The hero Parshurama later appears as a hero in the text of Sahyadri Khanda with the peopling of the coast and as the creator of the land of Sapta-Konkan (seven Konkans). The narratives on the peopling of Konkan also provide some clues for the social and cultural makeup of the area.

\section{Narratives on the Peopling of the Konkan Coast and Naming as the Process of Creation}

The critical edition of Sahyadri Khanda compiled in 1877 CE is replete with the details on peopling of the newly created land of Konkan. The new landmass was created so that the hero Parshurama could spend the

\footnotetext{
1 Udayasundarikatha is a medieval Sanskrit text written by Soddala as a novella on the ruling families in Konkan.

${ }^{2}$ Sthala Mahatmya is an umbrella term for texts which narrativize the importance of a site (Sthala = place/region, Mahatmya = praise).

3 Rocher enumerates the "Lakshanas" or characteristics of Puranas. The descriptions of cosmic order, the hierarchy of kings and gods alongwith the chronology are some of the characteristics of "Lakshanas". Levitt describes Sahyadri Khanda to furnish such details to establish its affinity with the Puranic literature.

4 The text of Sahyadri Khanda ascribes the name "Konkan" to the coastal region associated with the modern state of Maharashtra. Some of the other six regions under Sapta-Konkan are Telanga, Barabara, Keral, and Gokarna associated variously with modern Karanataka and Kerala coasts along western India.
} 
remainder of his days absolving the sin of killing the warriors. However, Konkan was then devoid Brahmins to perform the rituals for purification. Brahmins from other regions of South Asia were then invited to make Konkan their home. The sections Patitagramanirnaya and Chittapavanvyutpatti from the text of SK supplement the main narrative with the details on migration and the communities in Diaspora in relation to the peopling of Konkan coast. The migrants from faraway lands (Karve, 1932), fishermen (Pusalkar, 1955), and some Brahmanas resurrected from 14 corpses washed ashore (Chapekar, 1966), feature as the first inhabitants of Konkan. The text of Udayasundarikatha attributed to Soddala (1026-1050 CE) notes his fleeing to Konkan along with the hordes of migrants from the areas of Sindh and Gujarat in search of "god's land" (Sharma, 2004). These legends make for an intriguing topic, which deserves a separate dedicated discussion not included in the current exploration.

As a part of this creative process-creation of a new landmass and habitation on this land, the naming of sites on this bespoke landscape features as a cultural process in its own light. Parshurama named the coastline along modern Maharashtra after his mother, Kunkuna (Pusalkar, 1955) (also known as Renuka from the Puranic tradition). Basso (1984), in his study of Apache Indian landscape, opined that the landscape is full of named locations, to facilitate the fusion of time and space. He further elaborates that the features of the landscape perform symbolic functions which are omnipresent moral forces rather than mere physical entity. The same holds true for Konkan, as the medieval documents label Konkan as "Rama-kshetra" (region or locale of Rama) after Parshurama (Thomas, 2014) ${ }^{5}$ and the land is equated with morality and righteousness of the mythic hero. The naming of the coastline, the hills, the rivers, and the sacred groves (Kent, 2013) implies the act of naming as a constructive or creative process itself. The religious narratives from the text of SK tap into the processes of creation, absolving of the sins, and punishment for those who have wronged and a promise for lasting peace. In the naming of Konkan after Parshurama's mother, the creative and protective aspect of a mother is replicated onto the landscape. The Puranic episode of creation, alongwith Konkan as "home" to numerous communities in Diaspora as mentioned in SK and other allied texts elevate the landmass beyond mere physical geography.

The towns along the Konkan coast are identified as embodying specific narrative scheme from SK. The town of Sangameshwara, for instance, is described as the site to absolve sins (Mandlik, 1875) and a seat of Shiva, as implied by the suffix "eshwara" (Puranic, and now colloquial name for Shiva). The modern town of Chiplun, named variously as "Chitpolon", carries the narrative base as the site of purification from the corpses (chita, in Sanskrit) for its nomenclature. An alternate reading for Chiplun as a site where consciousness (chitta) of people was purified (pavan) is believed by some Brahmins in the town of Chiplun and alluded to by Deshpande (2010). The Brahmins who were resurrected at this site hence came to be known as "Chittapavan" (Chapekar, 1966). Following Basso's suggestion, the fusion of Puranic (generally equated with the early medieval) time and modern activity scape fuses with the continued place-names that resonate the local cultural scheme.

Local deities in the area follow the tradition of SK with close connection of the place names and the patron deities. The temples of Shiva named after the respective place at Velneshwar and Wadeshwar in addition to

\footnotetext{
${ }^{5}$ Numerous references of Parashurama appear in the Mahabharata, referring to him simply as "Rama". We are told that Parashurama chose the Parashu (axe) as his preferred weapon for defence, early on in his life. Parashurama belonged to the Bhargava lineage hence called Bhargava-Rama. Sahyadrikhanda assumes the knowledge of this background and switches between Parashurama, Rama, Bhargava-Rama, Bhargava-putra, and Parashu-dhari in the narration of the legends.
} 
Sangameshwar highlight this trend. Karve (1932) and Pusalkar (1955) alluded to the religious connotation borne by the sites on Konkani landscape. The modern studies by Levitt (2017) and Rao (2014) on SK further this place-name and regional culture dichotomy. Rao illuminates the various Sthala-Mahatmya associated with SK that link the physical places with mythic narrative by supplementing some origin stories or backdrop for sacred landscape. The lesser known texts appended to SK champion select sites of religious importance, which form a narrative link in the making of a microcosm along the western coast of India. The connectedness of these sites through a narrative link needs to be studied further for a nuanced understanding. The divine arrangement explicated in Sahyadri Khanda and the associated Sthala Mahatmya is subsumed under the geographic forms along the Konkan coastline.

\section{Creation of a Microcosm}

The narratives on religious space from SK are incorporated in the form of temples, etc. to animate the geography across the villages in Konkan. These edifices, in keeping with the religious Hindu narratives, simulate a sacred cosmos envisioned in the text. The performative aspect in the form of regular worship, appropriate material offerings and annual fairs for the deities construct a microcosm from the medieval text ${ }^{6}$. The microcosm encountered through cursory reading of Sahyadri Khanda, Venkatesh-Mahatmya (Betham, 1895), and Parshurama-Vijaya (Wagle, 1970) presents Konkan as a Hindu religious ideal. The temples dedicated to specific Hindu deities, such as Surya at Kaseli, Bhargava Rama at Chiplun, Mahakali at Adivre, Shiva at Sangameshwara (Bartakke, 2011) ${ }^{7}$, and so on, replicate the cosmic order from Sahyadri Khanda. A detailed study of these literary sources combined with the oral narratives in Konkan will enable further articulation of religious cosmos.

The confines of the physical landscape identified with the modern districts of Ratnagiri and Sindhudurg along the western coast encapsulate the cosmic order structured by Sahyadri Khanda. The mythic narrative sheds light on the migration to Konkan and elevates the Konkani coastline as a safe asylum created by divine intervention. Most of the resident Hindu communities in Konkan attribute their origin to one of the versions of the legends on populating the coastline as mentioned earlier. The text makes explicit remarks on the social hierarchy while relegating some groups of Brahmins on a lower rung owing to their devious and cunning ways (Deshpande, 2010). ${ }^{9}$ Ensuing from this sacred cosmology of the text, the spatial arrangements in the villages seem to align with the religious narratives. The localities for Brahmins in the villages of Ratnagiri district $\left(\right.$ Karve, 1963) ${ }^{10}$ are placed close to the village boundaries as opposed to the nexus of the settlement as observed in examples from Tamil Nadu (Valk, 2010) and other parts of Maharashtra (Feldhaus, 2003; Schlesinger, 1988). Simply put, one may conclude that the landscape, above all, represents a means of conceptual ordering that stresses social and religious relations (Feldhaus, 2003).

\footnotetext{
${ }^{6}$ The concept of microcosm as expressed in Konkan is relatable to the "Religious canopy" proposed by Berger and Luckmann (1966).

Bartakke (2011) and personal field notes from 2014.

8 This is not to say that the residents in the areas outside Konkan are unfamiliar with the narratives from the Sahyadri Khanda. The people in Konkani villages are however intimately connected with the narratives which are a part of their social life.

9 Peshwa Bajirao (1700-1740 CE), a Brahmin himself, had banned the text, and Gaitonde does not translate the sections in his Marathi translation of Sahyadri Khanda.

${ }^{10}$ With the exception of Chiplun and Rajapur, which are identified as the Brahmin majority areas.
} 


\section{Grounding the Hindu Narratives in Vernacular Space}

The literary religious lore constitutes an origin point in the form of a narrative, while introducing approximate temporality to the narratives on topography of Konkan. The temporality and grounding of the narrative is introduced through material culture, such as temples and sculptures. And the modern narratives preserved orally bind the spatio-temporal perpetuity of the religious tradition, as gleaned from some studies on ethnography and folklore in India (Narayan, 1997). All landscapes thus could be said to be embedded in social and individual time. In his work on the phenomenology of the landscapes, Tilly describes the lived present as a product of the pasts as much as the spaces in which previous activity has expressed itself. He goes on to champion social practices, such as public culture that binds space and cultural time together (Tilly, 1994). Stemming from Tilly's argument and other studies on spatio-temporal aspects of religious practice (Insoll, 2004; Sears, 2014), the discussion on religious space can proceed as assessing its various divisions (Tilly, 1994) ${ }^{11}$, binary of physical place and non-physical cosmos (Berger \& Luckmann, 1966) or as a canvas of permeable boundaries that is open to passage (Thompson, 1991).

The physical landscape along the Konkan coast is best described as a ritualised form rather than a backdrop for human or public action. The deification of local landscape as an animate form with fluid identity is apparent in Marathi ovi (short lyrical compositions) (Poitevin \& Rairkar, 1996) and kahani (Orsini, 2015) ${ }^{12}$. It is not farfetched to connect with Prithvi (earth) deified as mother, or national sentiments attached to the embodiment of land as Bharatmata (Ramaswamy, 2010). The boundaries between two villages of Konkan are deified as Chavhata-devi (threshold-goddess) allowing for the crossing of boundaries, generally rivers of streams. The crossing of waterbody is significant in Hinduism, which is a topic of separate discussion. The sacred groves are dedicated wild forest areas where human activity such as felling trees is considered a taboo (Kent, 2013). Some considerations on environmentalism could be gleaned from such efforts at conserving tree cover by assigning it to a deity. In the regional belief, however, the sacred groves function as the abode for semi-divine beings described in the Puranas that link the local and Puranic pantheon. The porous boundaries between two regions on a sacred landscape are largely governed by the cosmic order reinforced through performative tradition. For instance, entering the sacred grove from the village is generally a taboo; but on special days, such as new moon, a group of male villagers can enter the sacred grove to offer food for the deified grove (Youngblood, 2008; Kent, 2013). The minutiae of such sacred cosmos would be accessible only through an ethnographic study of the region.

The locals draw upon the religious narratives on territorialisation of Konkan in the arena of the recent feud over land ownership in the light of proposed nuclear power plants. Revivified Hindu nationalism as a part of current politics has led to new interpretations of the narratives from SK. A text can be taken as a momentary result of the textual practices that engages the participants as actors. That is, the text is open to interpretation in various points in time and the interaction with the reader, or performer in this case, is both dialogical and momentary. The tradition emerging as a scale of texts (Inden, 2000) (13 $^{13}$ cannot be assumed to be complete or

\footnotetext{
${ }^{11}$ Such as sacred and profane, following Durkheim's suggestion. Or Eliade's "Sacred time" which is the beginning of religious space in the sense of re-enacting the cosmological acts which stress the cyclical nature of sacred time intimately tying with the space it manifests. Cf. Tilly (1994). I do not subscribe to Durkheimian viewpoint, but some analysis from Eliade's thesis could provide an entry point into the temporal analysis.

12 "Kahani" means a story of narration of an episode. However, kahani with a " $n$ " implies religious lore in case of Maharashtra.

${ }^{13}$ Inden mentions the inter-textual dialogues as scale of texts. This incorporates the extra textual elements such as body practices, performance and the approaches of critiquing the text or tradition.
} 
dead (Inden, 2000; Coburn, 1980), but engages in the process of appropriation or criticism to position itself in relation to the history. The process of re-describing the modern narratives on Hindu religious geography in Konkan warrants further examination. The material sources of study combined with the data from oral testimonies of the modern population in Konkan will help build the understanding of the micro-level components in the making of the vernacular Hindu tradition.

The richness of the local microcosm unfolds in the case of Konkan with its literary tradition anchored in tangible culture, such as temples and posts (Biardieu, 1989). ${ }^{14}$ The copper-plate inscriptions from c. $900 \mathrm{CE}$ onwards aid to reconstruct the religious history of Konkan based on the patron deities and religious epithets mentioned in the inscriptions (Mirashi, 1977). The medieval temple at Chiplun village dedicated to Parshurama, the hero of Sahyadri Khanda fuses the Puranic narrative and religious performance by identifying a physical site to pin the mythological episode. The extant temples, and sometimes the memory of some religious edifices, add to the understanding of a complex idea, such as the intersection of physical geography and religious space through time. Furthermore, the sacred spots across the villages along the Konkan coast are connected through a narrative thread and human performative action. Feldhaus (2003) examined the importance of geographical places, spaces formed in shared belief system, and the experiential component of the devotees as the aggregates in understanding the meaning of sacred landscape in Maharashtra, which fits the case of Konkan. Feldhaus also highlights the ethnographic data in understanding the inter-connectedness between geographical sites and performative action, such as pilgrimage and ritual offerings. A micro-study of the local data which has escaped the scholarly attention so far will bring about the holistic understanding of the religious milieu of Konkan.

The historical records on Konkan spanning from medieval trade accounts to the British Colonial reports (Sheriff, 2010) add to the multi-faceted descriptions of the region with its ingrained cultural sphere of activity. The local historical records mention the Konkan coast as heavily guarded from the naval attacks by the local fleets, and isolated from the mainland by the Sahyadri hills to the east (Sheriff, 2010) which fostered a local Konkani culture. These historical sources further point at the groups of people engaged in religious reterritorialization based on Konkani narratives ${ }^{15}$. The deliberate attempts by the locals in history may provide a framework for maintaining identity and for defending theological claims for cosmic order. The commentary from various Jatipuranas (Bapat, 2001; Das, 2012) (clan-histories) hint at such processes, better understood by studying the unexplored kulavrittanta (family-histories) preserved in some families in Konkan. The author perceives this narration on sacred space as the moment of easing the inter-group dynamics and strife ${ }^{16}$, contained in some of the sections of Sahyadrikhanda (Levitt, 2017; Deshpande, 2010) ${ }^{17}$ and palpable in the modern society of Maharashtra.

\section{Creation of a Local Culture}

In addition to the insular culture of Konkan, the micro-level study addresses the process of popularisation of Hinduism of the Puranas in Konkan. Furthermore, the theoretical issues around the so-called elite and

\footnotetext{
${ }^{14}$ Madeline Biardieu's research on posts and lithic stelae charts out a robust framework for the study of lesser known boundary marker deities and deified spirits in South India.

15 Personal field notes, 2014.

16 Between Brahmin and non-Brahmin groups.

17 Sections of Patitagramanirnaya studied by Levitt and Deshpande's paper reveal the biases in textual description of Sahyadri Khanda. The presentation of Chittapavan Brahmins as converted fishermen and Karhade line of Brahmins as low, may point at the inter-group rivalries which exist to some extent to this day. Unacceptance of Saraswats Brahmins for the performance of religious duties is also highlighted in the text.
} 
non-elite religious practices are accessible through the case of Konkan. Conscious of the caveat of using Puranic material as mere illustrations in the past (Das, 2012), the discussion on larger thematic of religious geography needs to proceed as understanding of patterns and networks through case-studies. The sacralised space and the religious narratives as entry points into the social networks in Konkan will be the approached for this study. This angle of exploration, which moves towards the constructivist approach of studying sacred space (Warf \& Arias, 2009), stimulates a new dialogue in the field of Religious Studies. The articulation of public culture in the light of social networks becomes important in the study of vernacular Hinduism in Konkan. Locally deified elements, such as sacred groves and serpent deities are loosely termed as non-Sanskritic ${ }^{18}$, due to its ambiguous or non-existent literary anchors for study. The numinous local elements, such as deified groves or serpents reappear through local narratives, forging a temporal and spatial relationship with the popular Sanskritic narratives of the Puranas (Babar, 1968; Feldhaus, 1995; Deshpande, 2007).

The worshippers of the deities Vishnu and Shiva in India were considered as different sects prior to the umbrella term of Hinduism. These sectarian groups along the Konkan coast subscribe to a uniform cultural belief, as noted from the personal interviews. Vaudeville (1996) noted the fusion of sectarian Vaishnava and Shaiva boundaries in the medieval period as a part of assimilation with local deified elements across the country. The gradual merging of Shaiva faith into Vaishnava Bhakti of the saints is apparent in the case of Maharashtra (Fischer, 2017). The references from Marathi Bhakti poets, such as Ramadas (Deshpande, 2010) ${ }^{19}$ fuse the deities of Puranic fame with the local deifications of landscape. Furthermore, the traditional cults of non-Brahmins in Maharashtra for example, centre on Rudra-Shiva, Khandoba, Bhairava and several local goddesses (Vaudeville, 1996), while accepting the Vaishnava affiliation of Parashurama who in turn is the son of Shaivite sage, Jamadgni as described in the Puranas (Pusalkar, 1955). The deities associated with Brahmins and Kshatriyas gradually affiliate with the deities worshipped by Vaishya and Shudra community ${ }^{20}$ through narratives of marital alliance and so on (Ghurye, 1963). Thus, the conglomerate of Puranic and vernacular deities generally foregoes the sectarian affiliation, and as the modern case in Konkan suggests; the deities are worshipped as the deified forms and guardians of the local landscape. This homogeneity extends to the shared belief as sanctity of Konkan coast amongst the majority Hindu affiliates and some groups that self-identify as Muslim (Khan, 2004), highlighting a theistic acknowledgement rather than a sectarian leaning.

The literary and performative traditions shared by the Pan-Indic Puranas and local religious literature are presented as the undercurrent of the public culture in Chakrabarti's work on regional Mahatmyas in Bengal (Chakrabarti, 2001). Chakrabarti hypothesises the element of "form" of the deities as a Brahmanical or Puranic product, which absorbed the local village deities as a part of Puranic pantheon. The process of

\footnotetext{
18 The term "Sanskritic" pertains to the language as well as the suggestion of "civilized", based on the Marathi word Sanskriti for civilization. Numerous scholars have delved into the linguistic and sociological ramifications of the term. The corpus of literature produced between 1990s and 1970s made an explicit distinction between the "lesser" and "greater" traditions in South Asia, akin to Redfield's thesis (1969). The local religious sphere was designated as non-Sanskritic, also meaning less civilized. Such artificial compartmentalisation is problematic, as the experiential conglomerate of vernacular and so called popular or pan-Indic deity pantheons is inter-dependent. For instance, one cannot fully appreciate the divine nature of Parshurama without the later inclusion of Parashurama as one of Vishnu's incarnations (dasavtara). Similarly, the belief in Vishnu worship as Vishnu incarnating in every epoch, to bless specific devotees (across the subcontinent) cannot be reached at, without the regional incarnation narratives, such as that of Parashurama. The issue of elite and non-elite religious manifestations abates in the light of a fluid pantheon of deities in India.

19 Daasbodh II.6.12-29 by Ramdas, Cf. Deshpande (2010).

${ }^{20}$ I have retained the old and controversial nomenclature for this sentence; as the purpose was to highlight the social class affiliation with the respective deities. Let it be noted that I do not subscribe to this nomenclature.
} 
anthropomorphising of the divine developed from the embodiment of abstract spirit and folk-deities from non-textual traditions. Chakrabarti elaborates this central argument for deities in Bengal, as a "religious process". Chakrabarti describes the process of religious literature in Sanskrit as attempting to associate with popular regional texts to garner a larger following. Chakrabarti describes the process of Puranic assimilation as providing an inclusive religious umbrella with a range of narratives suitable for various social groups. In this process, the medieval vernacular texts were translated into Sanskrit to some degree, to expand on the relatedness of the Hindu compendium. The study of religious literature of Maharashtra, especially along the Konkan coast, in the medieval period presents ambiguous scenario in terms of its literary production. However, a similar process as elaborated by Chakrabarti may have been at play for the deities in Konkan. The local literary sources, such as kulavrittanta rely heavily on oral and aural traditions as the cursory study of these sources suggests. In his thesis on the Maharashtrian quotidian religious tradition based on aural literacy (Novetzke, 2007; Novetzke, 2015), Novetzke elaborates aural performative traditions as the background for Bhakti literature of the medieval period. Sahyadri Khanda and later regional texts in both Sanskrit and Marathi emerge as invaluable resources for the study of lesser-known deities and their aural traditions along the western coast of India.

The analysis of vernacular religion as public culture as described by Appadurai and Brekenridge (1988) for the case of South Asia provides a vantage point to approach the scope of religious narratives on geography. The term "public culture" as described by Appadurai and Brekenridge (1988) and Novetzke (2017) refers to the idea of a combined socio-cultural praxis of initially differentiated elite-non-elite, lesser-greater traditions in non-bounded societies. An attempt to incorporate the voice of people beyond the privileged sections of the society is alluded to in the studies on public culture in modern scholarship (Flueckiger, 1996). The lens of public culture is helpful to address the variegated scape of religious activity and literary production in Konkan and its surrounding areas. The intersection of Sanskritic and non-Sanskritic traditions of literary production provide the access points to understand the possible underlying networks in the making of a local ritual base. The study of public culture incorporates the less-privileged sources of study in the form of oral and aural testimonies. Aural retrieval pertains to the retelling of narratives or discourses that are heard by the respondent. Performances of dramatization and music are often added to this category. The retelling of Puranic legends and re-enactment of mythological episodes as a part of aural source on public celebration could be incorporated in the study of public culture.

\section{Concluding Remarks}

The narratives from the medieval text of Sahyadri Khanda sketch out the cultural milieu along the west coast of India of the medieval period. Parashurama as the creator of the landmass of Konkan features as the main theme for the sacred landscape in the area. The divine agency in the creation of Konkan extends to the naming of the coastline after Parashurama's mother, Renuka or Kunkuna. This creative process of naming the landscape has contributed in the making of a regional cultural tradition. The local deities and the associated place names contribute to the vernacular belief system. As pointed out in this short exploration, the variegated religious backdrop along the Konkan coast has contributed to shared belief system under the umbrella term of Hindu beliefs.

This exploration is not to champion the "Hinduness" of the narratives on local landscape in Konkan, but on the contrary, to bring to attention the triumph of vernacular socio-cultural belief that rests in these religious 
narratives. The local adaptation of numerous deities mentioned in SK is one of the prominent facets of what Chakrabarti calls the "Religious Process". SK features as an authoritative text on religion and sacred narratives on space, further influencing the social hierarchy mandated by Hinduism. The local deity sphere as a part of performative sphere in the modern times transcends the textual boundaries set by SK while drawing the source for legitimation of the deity sphere from the medieval text.

These processes of appropriation through the aural and performative actions have contributed to the vernacular cultural milieu of Konkan. A detailed study of the textual tradition, material culture and associated performative tradition in the modern period will aid the understanding of the local culture long the west coast of India, which has been thus far overlooked.

\section{References}

Appadurai, A., \& Brekenridge, C. (1988). Why public culture? Public Culture, 1(1), 5-9.

Babar, S. (1968). Folk literature of Maharashtra. Bombay: Government Central Press.

Bapat, J. B. (2001). The Jātipurāṇas of the Gurava Temple Priests of Maharashtra. International Journal of Hindu Studies, 5(1), 45-90.

Bartakke, S. (2011). Konkanatil Devalaye (In Marathi). Pune: Parchure Prakashan.

Basso, K. (1984). Stalking with stories: Names, places and moral narratives among the western Apache. In E. Bruner (Ed.), Text, play and story. Illinois: Waveland Press.

Berger, P., \& Luckmann, T. (1966). The social construction of reality: A treatise in the sociology of knowledge. New York: Doubleday and Company.

Betham, G. K. (1895). Specimens of modern Brahmanical legends, No. 1-Manjguni-Purāṇa (Venkatesa-Māhātmya from Mahāpurāṇa Sahyādrikhaṇḍa). Indian Antiquary, 24, 231-242.

Biardieu, M. (1989). Stories about posts: Vedic variations around the Hindu Goddess. (A. Hiltebeitel, M. L. Reiniche, and J. Walker, Trans.). Chicago/London: The University of Chicago Press.

Chakrabarti, K. (2001). Religious process: The Purānas and the making of a regional tradition. New York: Oxford University Press.

Chapekar, N. G. (1966). Chittapavan (In Marathi). Pune: Parchure Prakashan.

Coburn, T. (1980). The study of the Puranas and the study of the religion. Religious Studies, 16(3), 341-352.

Crawford, A. (1909). Legends of the Konkan. Allahabad: Pioneer Press.

Da Cunha, J. G. (Ed.). (1877). The Sahayādri-khaṇ̂a of the Skanda-Purāna: A mythological, historical and geographical account of Western India. Bombay: Thacker \& Vining.

Das, V. (2012). Structure and cognition: Aspects of Hindu caste and ritual (4th ed.). New Delhi: Oxford University Press.

Deshpande, M. (2010). Panca Gauda and Panca Drāviḍa: Contested borders of a traditional classification. Studia Orientalia, 108, 29-58.

Deshpande, M. N. (1995). Some aspects of folk religion in the Konkan and Desh regions of Maharashtra. In G. D. Sontheimer (Ed.), Folk culture, folk religion and oral traditions as a component in Maharashtrian culture. New Delhi: Manohar Publications.

Deshpande, P. (2007). Creative pasts: Historical memory and identity in Western India 1700-1960. New York: Columbia University Press.

Enthoven, R. E. (1920-1922). The tribes and castes of Bombay (Vol. 3). Bombay: Government Central Press.

Feldhaus, A. (1995). Water and womanhood: Religious meanings of rivers in Maharashtra. New York/Oxford: Oxford University Press.

Feldhaus, A. (2003). Connected places: Region, pilgrimage, and geographical imagination in India. New York: Palgrave Macmillan.

Fischer, E. (2017). Hindu pluralism: Religion and the public sphere in early modern South India. Oakland: University of California Press.

Flueckiger, J. B. (1996). Gender and genre in the folklore of Middle India. Ithaca/London: Cornell University Press. 
Gaitonde, G. S. (Trans.). (1971). Śrī Skandapurāṇa, Sahyādrikhaṇđa, Do. Jarsana da Kunhā sampādita granthācī samśodhita, samvardhita āvṇti, Marāthī arthāsaha (The text of the Sahyādri-khaṇda as established by J. Gerson da Cunha, with Marathi translations). Mumbai: Shri Katyayani Publications.

Ghurye, G. S. (1963). Anatomy of a Rururban Community. Pune: Popular Prakashan.

Goffman, E. (1959). The presentation of self in everyday life. Ithaca: Anchor Books.

Habib, I. (2008). Medieval India: The study of a civilization. New Delhi: National Book Trust.

Inden, R. (2000). Introduction: From philological to dialogical texts. In R. Inden, J. Walters, \& D. Ali (Eds.), Querying the medieval: Texts and the history of practices in South Asia. New York: Oxford University Press.

Insoll, T. (2004). Archaeology, ritual, religion. New York: Routledge.

Karve, I. (1932). The Parasurāma myth. Journal of the University of Bombay, 1, 115-139.

Karve, I. (1963). The new Brahmans. Berkeley: University of California Press.

Kent, A. (2013). Sacred groves and local gods: Religion and environmentalism in South India. New York: Oxford University Press.

Khan, D. S. (2004). Crossing the threshold: Understanding religious identities in South Asia. London: I. B. Tauris Publishers.

Levitt, S. H. (1982). The Sahyādrikhaṇda: Style and context as indices of authorship in the Patitagrāmanirṇaya. Purāṇa, 24(1), $128-145$.

Levitt, S. H. (2017). The Pātitagrāmanirṇaya: A Purāṇic history of some Brahman communities. Delhi: Motilal Banarasidas.

Mandlik, V. N. (1875). Sangamesvara Māhātmya and Linga worship. The Journal of the Bombay Branch of the Royal Asiatic Society, 11, 99-114.

Mirashi, V. V. (Ed.). (1977). Inscriptions of the Silaharas. Corpus Inscriptionum Indicarum (Vol. 6). New Delhi: Director General, Archaeological Survey of India.

Narayan, K. (1997). Mondays on the dark night of the moon: Himalayan foothill folktales. New York: Oxford University Press.

Novetzke, C. L. (2007). Bhakti and its public. International Journal of Hindu Studies, 11(3), 255-272.

Novetzke, C. L. (2015). Note to self: What Marathi Kirtankars' notebooks suggest about literacy, performance, and the travelling performer in pre-colonial Maharashtra. In F. Orsini \& K. B. Schofield (Eds.), Tellings and texts: Music, literature and performance in North India. New Delhi: Open Book Publishers.

Novetzke, C. L. (2017). The quotidian revolution: Vernacularization, religion, and the premodern public sphere in India. New Delhi: Permanent Black.

Orsini, F. (2015). Texts and tellings: Kathas in 15th-16th centuries. In F. Orsini \& K. B. Schofield (Eds.), Tellings and texts: Music, literature and performance in North India. New Delhi: Open Book Publishers.

Poitevin, G., \& Rairkar, H. (1996). Stonemill and Bhakti: From the devotion of peasant women to the philosophy of swamis. New Delhi: D.K.Printworld.

Pollock, S. (2009). The language of the gods in the world of men: Sanskrit, culture, and power in pre-modern India. Oakland: University of California Press.

Prange, S. (2011). A trade of no dishonour: Piracy, commerce, and community in the Western Indian Ocean, twelfth to sixteenth century. The American Historical Review, 116(5), 1269-1293.

Pusalkar, A. D. (1955). Parasurama and the Konkan. In P. K. Narayana Pillai (Ed.), Kerala studies, Prof. A. Gopala Menon commemoration volume (pp. 1-13). Trivandrum: University of Travencore.

Ramaswamy, S. (2010). The goddess and the nation: Mapping mother India. New Castle: Duke University Press.

Rao, N. (2014). Gramapaddhati: A medieval text from South-western India. Vidyasagar University Journal of History, 3, $27-37$.

Rocher, L. (1986). The Purānas. Weisbanden: Otto Harrasowitz.

Rohlman, E. (2011). Geographical imagination and literary boundaries in the Saraswati Purana. International Journal of Hindu Studies, 15(2), 139-163.

Schlesinger, L. (1988). Clan names, dominance and village organisation: Bhonsale and Kadam in Apshinge. In D. Attwood et al. (Eds.), City, countryside and society in Maharashtra. Toronto: Centre for South Asian Studies.

Sears, T. (2014). Worldly gurus and spiritual kings: Architecture and ascetism in Medieval India. New Haven: Yale University Press.

Sharma, S. K. (2004). Udayasundarikatha of Soddala: Text, translation and annotations. Delhi: Parimal Publications.

Sheriff, A. (2010). Dhow cultures of the Indian Ocean: Cosmopolitianism, commerce and Islam. New York: Columbia University Press. 
Thomas, L. (2014). Parashurama and time. In J. Leslie (Ed.), Myth and mythmaking: Continuous evolution in Indian tradition. New York: Routledge.

Thompson, L. (1991). Mapping an apocalyptic world. In S. Simpson (Ed.), Sacred places and profane spaces: Essays in the geographics of Judaism, Christianity, and Islam. New York: Greenwood Press.

Tilly, C. (1994). A phenomenology of landscape: Places, paths and monuments. Oxford: Berg.

Valk, Ü. (2010). Caste divisions in the religious folklore of Tamil Nadu. Anthropos, 105, 205-213.

Vaudeville, C. (1996). Myths, saints and legends in medieval India. Delhi: Oxford University Press.

Wagle, N. (1970). The history and social organisation of the Gauḍa Sāraswata Brāhmaṇas of the West Coast of India. Journal of Indian History, 48, 7-25, 295-333.

Warf, B., \& Arias, S. (Eds.). (2009). The spatial turn: Interdisciplinary perspectives. New York: Routledge.

Youngblood, M. (2008). Negotiating hierarchy and identity: Cultural performances on the meaning of the Demon King Bali in Rural Maharashtra. In M. Bhagvan \& A. Feldhaus (Eds.), Speaking truth to power: Religion, caste, and the subaltern question in India. New Delhi: Oxford University Press. 